\title{
Violence, Science, and Cotton in Colonial-Fascist Mozambique (1934-1974)
}

\section{Violência, Ciência, e Algodão no Moçambique Colonial-Fascista (1934-1974)}

\author{
Paulo Guimaraes, \\ University of Évora, Portugal
}

\begin{abstract}
Since the 19th century, Portuguese authorities had made unsuccessful attempts to promote cotton production in Angola and Mozambique. Under colonial fascist rule, the cotton plantations expanded significantly to meet the demands of the Portuguese textile industry. Eventually, cotton became the major agricultural export in Mozambique. This text explores the causes for this success, focusing on the rapid growth of indigenous cotton fields in northern Mozambique. In our research, we analysed contemporary "grey" cotton scientific literature, labour legislation, administration reports, agronomical thesis and the extensive collection of anthropological and social history studies carried out since the 1970s. We demonstrate that fascism created a specific model for the exploitation of humans and nature. This model involved labour mobilization based on daily physical and psychological violence and the humiliation of the indigenous people, the promotion and advancement of colonial cotton science for the industrialization of nature, and the creation of new economic institutions and rules to promote neo-mercantilist policies.
\end{abstract}

Keywords-Cotton Plantation; Colonial Science; Indigenous Agriculture - Portuguese Mozambique - Estado Novo.

Resumo-Desde o Século 19, as autoridades portuguesas tentaram, sem sucesso, promover a produção de algodão em Angola e Moçambique. Sob o domínio colonial-fascista, as plantações de algodão expandiram-se significativamente para satisfazer as necessidades da indústria têxtil portuguesa. O algodão tornou-se o maior produto de exportação agrícola em Moçambique. Este texto explora as causas deste sucesso, com foco no crescimento rápido dos campos de algodão indígenas no norte de Moçambique. Na nossa investigação, analisamos a literatura científica cinzenta contemporânea sobre o algodão, a legislação, os relatórios administrativos, as teses agronómicas e a extensa coleção de estudos antropológicos e de história social realizados desde os anos 70. Demonstramos que o fascismo criou um modelo específico para a exploração do homem e da natureza. Este modelo envolveu a mobilização laboral baseada na violência física e psicológica quotidiana e na humilhação dos povos indígenas, a promoção e o avanço da ciência do algodão colonial para a industrialização da natureza, e a criação de novas instituições económicas e regras para promover as políticas neo-mercantilistas.

Palavras-Chave-Plantação de Algodão; Ciência Colonial; Agricultura Indígena - Moçambique Português - Estado Novo.

Submitted-09-08-2021. Accepted-05-11-2021.

- Paulo Guimarães, Assistant Professor at the University of Évora and Integrated Member of the Research Center in Political Science (CICP).

E-mail: peg@uevora.pt 


\section{Introduction}

The propaganda of the Portuguese New State combined traditionalist discourse (in that images of the region's rural and human-impacted landscapes became part of the national identity) with the historical narrative that the Portuguese nation had a divine mission to spread Catholicism in order to 'civilize' other 'inferior' peoples. However, the new political elites did not create new visions for the African colonies. In 1929, at the beginning of the Salazar's era, a set of luxurious large-format albums published in Lourenço Marques (now Maputo) used photography to celebrate the new colonial world, showcasing Mozambique's 'very rich' potential for Africanist investors and adventurers (Rufino 1929). Alongside photos of the material remains of the Portuguese presence, such as churches and military fortifications, there were images of the rapid on-going transformation: new villages, geometrically-structured missions and hospitals, roads, ports, bridges and railway stations. These new monocultural landscapes were built by companies and entrepreneurs throughout territory, and the indigenous peoples who lived there soon became integral aspect of these landscapes. Rubber and tobacco plantations in Macanga (Tete), as well as coal mines in Moatize, demonstrated great entrepreneurial success. In one photo taken in Mucojo (Macomia), off the coast of Cabo Delgado, four Muslim men in the palm plantation of the Agricultural Company of Goludo help four oxen with Portuguese yokes plough the land with an iron plough. In another photo, we see indigenous palms and a local dwelling. Taken further inland, in Montepuez, is an image of the sisal monocultures of the German Hoffman's property. Moving to the central region, in Zambézia, we see the sisal baling factories of the Companhia de Moçambique, new settlements made of huts arranged in uniform lines, and camps for indigenous workers who also 'trained oxen to work', forcing them to walk in circles while attached to a pole all day. The same disciplined environment was repeated in Quelimane, on the property of M'Baza, where tobacco and corn were produced to feed the workers. In these new mono- cultural landscapes, the indigenous people found themselves ranked alongside cattle as the essential tools of the civilizational transformation taking place. In one photo, men appear huddled as a group of slaves, thin and tired.

In the last volume, the Fauna section contains a collection of images of a white hunter and his kills. He is pictured with his rifle, showing off the horns of the pacaças (syncerus caffer) and the antelope (aepyceros), the teeth and feet of elephants (loxodonta africana), which were still plentiful south of the river Save, and finally, the carcasses of baboons (Papios cynocephalus). Sometimes we find other hunters in the background - men who had recently been conquered, and who were then reduced to being the white man's hunting assistants. Naked, they transport a dead leopard (Panthera pardus) tied to a stick. The message of the photographs is clear: the fauna exists to be hunted and to celebrate the dominance of the white man and his rifle over Africa.

The colonizers noticed a profound difference in their relationship with nature, compared to that of the people who lived there. For example, the hunting practices of the indigenous people were different from the mass slaughters of white hunters, because 'they were not, then, as they are not today, processes that would put the species extinction at risk' (Martinho 1934,3). ${ }^{1}$ Thus, wild animals would face certain extinction outside the reserves 'that to a certain extent prevent their destruction on a large scale (...) proved by this inexorable law of civilization'. These hunting reserves were created in response to those large killings, as well as to the foreseeable increase in the local human population and the concurrent expansion of agriculture. This would be the only way for mammals to survive in the new era. Additionally, these reserves showed great potential for the tourism industry. In this time period, African landscapes were seen as wild, uncultivated, and lacking human labour - spaces that must be conquered and exploited. In addition, the development of many areas was dependent on scientific advances that would make it possible to combat diseases such as African trypanosomiasis

1. All quotes from the Portuguese documents were translated by the author. 
(Trypanosoma brucei) that plagued humans and animals, especially in the northern parts of the region (Cabo Delgado and Niassa).

This Africa, now presented as the 'hunter's paradise', would inevitably be on the same evolutionary path of Europe and the Americas, as it possessed an unexplored market value. It was an immense territory to be civilized through the work of the subjugated peoples. Conservationism was inseparable from the capitalist values that would irreversibly transform the relationship of humans with their environment, creating new landscapes dominated by agricultural and forestry monocultures. In addition to the protection granted by provincial governors to large companies and white agricultural settlers in the territory, rural communities were increasingly being compulsorily mobilized to accommodate the production of cotton, rubber, rice, and other export goods dependent on the supply of cheap indigenous labour. In the last days of the Republican regime, the Ross Report for the Temporary Slavery Commission of The League of Nations denounced the level of barbarism and exploitation of men in the Portuguese colonies (Ross 1925).

How different was this new fascist regime regarding the African environment? The new political regime mobilized the military and civil society towards the colonialist ideal in the midst of rising criticism against the violent practices of Portuguese colonialism. In 1930, the military dictatorship legislated the Colonial Act in response to 'certain international currents' that 'tend to agitate or establish ideas unfavourable to the traditional dogmas of the colonial sovereignty of the metropolises, often covering up the designs of imperialism with humanitarian principles' (decree 18.570). Moreover, the new regime placed the colonies at the centre of its nationalist program, integrating the Colonial Act into the Constitution of 1933. The imperial vocation of Portugal was to be exercised through the 'possession and colonization of overseas domains' and the 'civilization of its indigenous populations'.

The institutionalization of the colonial New State set in motion a new cycle that began during the dictatorship and enabled the expansion of cotton farming by increasing the mobilization of rural communities under the supervision of a hi- erarchy of both 'traditional' and colonial authorities. The previous plan of colonization through the progressive settlement of white farmers, who were supported by bank credits, chemical technologies, machinery, and above all, by indigenous workers living in reserves, had failed (Fortuna 1994, 103). While Portuguese historiography has highlighted corporatism as an essential feature of the new regime, the expansion of cotton production in the colonies for the metropolitan textile industry demonstrated its neo-mercantilism (Clarence-Smith 1985; Leite 1989). Until 1934, cotton production did not exceed, on average, 1,6 thousand tonnes (tt). However, by 1970 it had reached 140 tt in order to meet the growing demands of the Portuguese textile industry (Quintanilha, 1955, p. 3; Mozambique, 1976). The military dictatorship (1926-1933) initiated the expansion of cotton farming by coercing rural communities to cultivate cotton, subordinating those peoples to the role of collective 'indigenous growers' (machambeiros). In Mozambique, indigenous production went from around $15 \mathrm{tt}$ in the late 1930s to more than 70 tt in 1942. Ten years later, it surpassed 300 tt (Quintanilha 1954, 7). By 1940, the area devoted to cotton cultivation in Mozambique had risen to about 200 thousand hectares (th), mobilizing about half a million forced cultivators - a number that would increase significantly in the following years (Quintanilha 1948, 10). During this period, cotton production in northern Mozambique surpassed that of Angola and the rest of the colony. Cotton soon became the primary indigenous crop, and would remain so until the end of the war of independence in 1974. In addition to cotton, though considerably less significant in both quantity and value, indigenous crops included copra and food crops such as peanuts, rice, cashew nuts, corn, manioc, beans and other vegetables (Beatriz 1946). In 1970, cotton covered over 350 th throughout the territory, and was being produced in the overwhelming majority by African families who worked in a system of capitalist concessions under the tutelage of the colonial state. These new cotton cropscapes were created through collective physical violence, and reoriented food production from a self-sufficient model to dependence on international trade. They became a major source of poverty, malnutrition, 
and hunger.

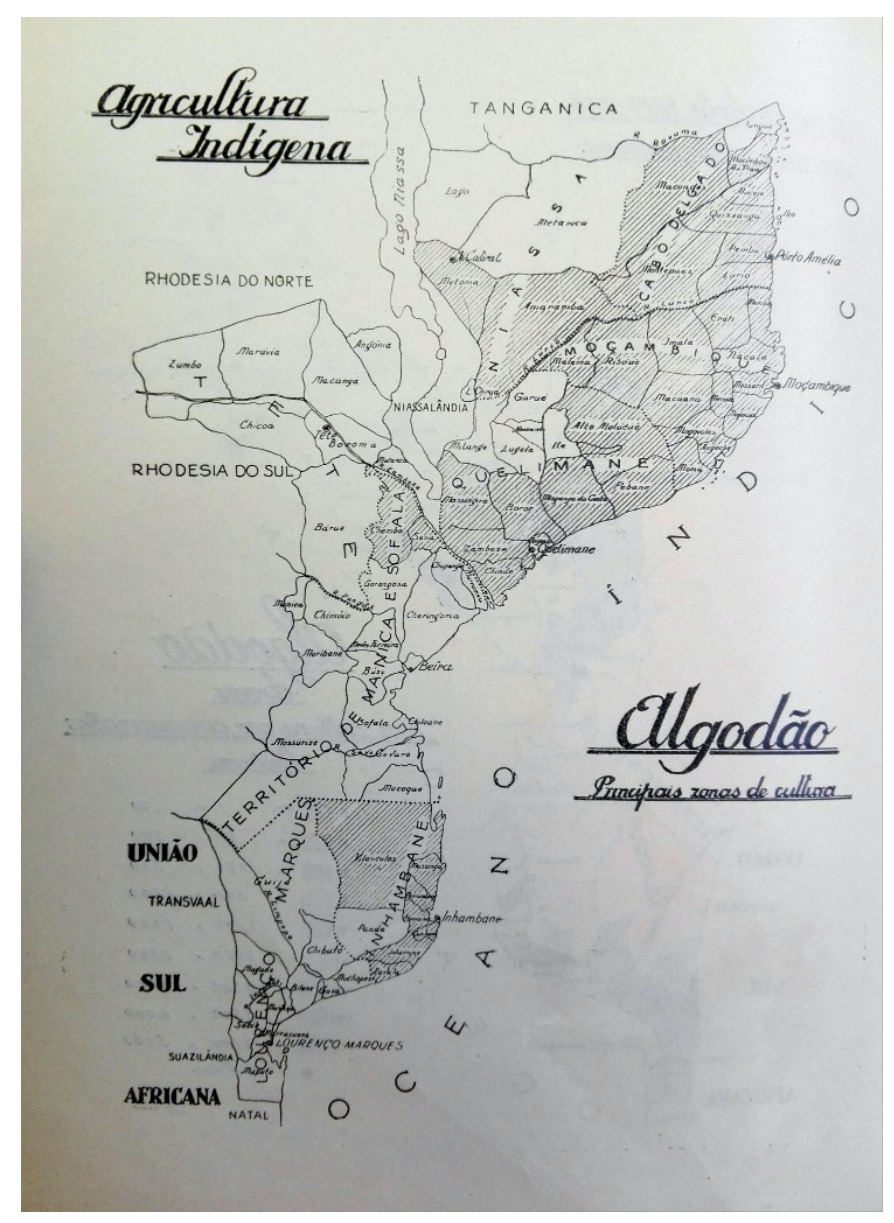

Figure 1: Cotton regions (zonas algodoeiras) in Mozambique under the regime of forced indigenous farming (grey areas) (Mozambique 1934).

The expansion of industrial cotton fields created environmental imbalances that manifested in insect plagues and soil erosion. Moreover, unpredictable weather was also a major risk that affected land and labour productivity, as well as the quantity and quality of the cotton. The development of scientific institutions that communicated their knowledge to indigenous farmers became an essential pillar of this colonial-fascist regime. The instructions laid out by these institutions were considered vitally important, and farmers who failed to follow them were severely punished. The creation of new administrative economic institutions and administrative prices guaranteed profits for cotton concessionaires, exporters, and industrialists; this became the third pillar of the success of the cotton industry during the Estado Novo period (Pitcher 1991, 1995). In this text we ex- plore the three dimensions of Portuguese colonialfascism through its cotton policies in Mozambique from 1926 to 1975: the industrial mobilization of nature, the development of cotton science, and the making of the contemporary African peasant class.

Much like coerced labour in the mining industry and large agricultural estates, the expansion of the forced cotton cultivation scheme was a collective painful experience that would constitute one of the elements that brought together different cultural identities in the anti-colonial struggle. Both during the anti-colonial war and after independence, this experience was often invoked by FRELIMO for the cause of political unity and mobilization (Mondlane 1969; Oliveira 2019). The Makonde plateau in Cabo Delgado became the one major centre of clandestine organization since the late 1950s, and was also the origin of the armed struggle that began years later, led by FRELIMO. These events marked the beginning of a new chapter of Mozambican nationalism (Mondlane 1969; Correia 2019). The 'Mueda massacre', a tragic incident that occurred on June 16, 1960, between the Portuguese authorities and the Makonde peoples subjected to forced cotton production, became the foundational myth of the modern anti-colonial struggle of the new-born Mozambican nation.

Given this context, it is not surprising that the experiences of cotton farmers in colonial Mozambique have been the focus of abundant historical research since the country's Independence. Research missions from the Center of African Studies (CEA) at the University Eduardo Mondlane led to long-lasting historiographical controversies (Adam \& Gentili 1984; Adam and Dyuti 1993; Adam 1996; Cahen 2018). Using the colonial documents gathered by the Historical Archive of Mozambique and the reports of colonial inspections deposited in the Arquivo Histórico Ultramarino (Lisbon), in-depth regional studies on this event have continued to emerge in the following decades. That research has drawn its data not only from the investigation of colonial archives, but also from the use of interviews to actively gather local memories that document the coercion, brutality, terror, racism, hunger, and even the myopia of the daily practices of colonial au- 
thorities and agents. (Adam \& Gentili 1984; Adam and Dyuti 1993; Adam 1996; Isaacman-1994; Isaacman \& Roberts-1995; Adam-1996; Manghezi 2003). Comparative analysis of colonial cotton policies and gender perspectives has also contributed to the body of research. Anne Pitcher demonstrated the key role of the brutal methods of coercion used on women and men to explain the failure of the expansion of cotton cultivation since the liberal period, as well as the reasons for its subsequent success (Picther 1991; see also in 1992). Social historians and anthropologists have also documented the daily practices of indigenous resistance against forced cotton cultivation (Isaacman 1994; Isaacman \& Roberts 1995). In the wake of critical reports produced in the context of the anti-colonial struggle, historians have also taken interest in the 'collaborationism' of those oppressed by colonialism. Emphasizing bottom-up approaches, they have compared 'cotton colonial regimes' and their consequences on food security and social behaviour with various other courses of action that would have impoverished the majority and caused substantial and irreversible changes on African societies and landscapes. Many of the results of these investigations carried out in Mozambique after the independence at the CEA would be disseminated internationally in the 1990s and even later (Isaacman 1994; Isaacman \& Roberts 1995; Adam 1996; Manghesi 2003). In the last few decades, these narratives have tended to integrate post-colonial analysis of social and political change as a continuum of institutional violence and poverty (Jones 2002, Dinerman 2016).

On the other hand, economic historians of Portuguese colonialism have underlined the 'classical' neo-mercantilist nature of the Colonial Pact. This is illustrated by the expansion of cotton in the colonies for the metropolitan textile industry (Clarence-Smith 1985; Leite 1989; Fortuna 1993). However, the role of arbitrary daily violence was also highlighted by Carlos Fortuna (1993), who described this practice within the framework of the colony's integration into the world economy. In this context, both Leite (1989) and Fortuna (1993) analysed the role of the new institutional framework, especially the Junta de Exportação do Algodão Colonial (JEAC), which was created in 1938 (Portugal 1938). Fortuna calls the new fascist era the period of 'black cotton', as opposed to the former 'white cotton' system, highlighting the capitalist settler's agricultural model that failed in the 1920s due to the fall of international prices. The value of cotton for the Mozambican and Portuguese economies was also explored, bolstered by the data accumulated in previous studies (Quintanilha 1966; Bravo 1963; Leite 1989). Joana Pereira Leite, expanding on the data provided by Alexandre Quintanilha, noted the importance of the application of scientific knowledge to indigenous agriculture during the 1940s and 1950s, which enabled the economic development of the colony under the Colonial Pact (Leite 1989, II, 229-230). More recently, Tiago Saraiva (2009, 2016) shed light on the role of scientific institutions in the Estado Novo policies, and compared them with the role of similar institutions in other fascist regimes.

This text benefits from this cumulative research in order to succinctly describe the key elements of the historical processes that led to the major civilizational and environmental change of the colonial-fascist era in Mozambique. For this purpose, we chose to focus on the expansion of cotton fields in northern Mozambique. We argue that this major change was achieved through the combination of non-liberal economic nationalism, the investment in colonial agronomic science, and the mobilization of labour through the barbaric treatment of colonized populations. We explore these three dimensions of the cotton industry that helped set in motion the irreversible trajectory towards environmental imbalances that accompanied the formation of the contemporary nationstate.

\section{The origins of 'black cotton': civiliz- ing through work}

Early attempts to produce cotton in Portuguese Africa date from the time of Marquis of Pombal. However, state-sponsored and export-oriented agrarian capitalism was successful only in Brazil (mostly in Maranhão and Pernambuco) through two different models: large estates based on slavery and small unit production by white settlers (Pereira 2018). After the independence of Brazil, and during the Liberal Era, there was been a 
systematic effort on behalf of the governors of Angola to increase production through various incentives for settlers, such as the guarantee of purchase, bonuses, or exemption from military service. During the US Civil War period, at a time when prices were rising, the government authorized the governors of Angola and Mozambique to award concessions of 4,5 thousand acres. At the same time, they advanced 20 contos de réis and exempted from taxes the importation of machinery for the production and preparation of the raw material (Pitcher, 1991). The failure to expand cotton cultivation in the regions of $\mathrm{Lu}-$ anda, southern Angola and southern Mozambique was due both to natural causes (climate, seed quality, pests, and diseases) and to difficulties in marketing that were aggravated by falling prices on world markets (Pitcher, 1991). By the middle of the 19th century, the Bantu populations in various regions of Angola and Mozambique had marginally adopted cotton production for consumption. The expansion of cotton cultivation until the military dictatorship (1926-1933) followed the settlers model based on large and mediumsized plantations that were run by Europeans and worked by Africans who had been expelled from fertile lands, recruited in reserves, and obliged to pay the hut tax. However, extensive cotton plantations required technical and scientific knowledge that was unavailable to both white farmers and to the rural communities that had to the pay the hut tax (imposto de palhota) for this commodity. The arrival of new colonizers often meant entire communities were either forced to relocate to poorer lands or be subjected to the role of tenants (Neves 1998). By the eve of World War I indigenous agricultural production across multiple African territories had increased to meet the growing tax burden imposed by the colonizer. The goods used to pay these taxes, such as cotton, rice, or corn, then entered the commercial marketplace. Despite these efforts, by the end of the republican period, cotton production in Angola and Mozambique was still far from sufficient to meet the needs of the growing Portuguese cotton textile industry.

Since the beginning of the 20th century, attempts to introduce cotton culture in the territories of the Chartered Companhia de Moçambique were accompanied by propaganda campaigns that promised better living conditions for rural populations. Men would be exempt from compulsory work that kept them away from home for many months and left women by themselves. However, they were subject to the surveillance and guidance of company supervisors. Unforeseen infractions, neglect, or breaks in production were punished with the palmatória (a wooden paddle-like instrument) or the dreaded chamboco (a whip made from rhinoceros hide). The offenses were often due to the fact that farmers struggled to meet the competing demands of both cotton farming as well as food production. The amounts paid to producers were subject to fluctuations in the international market, often aggravated by dishonest prices charged by the buyer. One way to compel the populations of a region to opt for cotton cultivation was to increase the hut tax in such a way that other options would become unfeasible. The result of this was often an increase in disciplinary violence, migratory escapes, malnutrition, hunger, and tensions with colonial authorities (see, for example, Neves 1998, 181; Isaacman 1985).

The colonial-fascist regime generalized these practices throughout the territory. Following the 'Belgian Model' of cotton production, the colonial administration delivered vast areas of the districts to a few concessionaires who held a monopoly on industrial preparation and local trade, while simultaneously mobilizing indigenous agriculture. The historiography on Portuguese in Mozambique has abundantly documented the worsening of the brutality towards black farmers. Despite international criticism, this practice was considered necessary for the mobilization and intensification of agricultural work. Colonial administrators believed that they were creating an African peasant class. The idea that the Bantus were peasant peoples, in the same way as Europeans or Asians, was an odd notion to the colonizers at the time. As often colonial reports remark, the Bantus had a 'primitive' itinerant agriculture, using poor tools and no animals to work, and until recently they had been hunters, warriors, and traders. The widespread and recurring representation of Bantu societies expressed in administrative documents and in works of great dissemination such as that of Rufino, was that agricultural work was performed by women, and that men, due to hunting, war, 
and other activities, were reduced to vagrants who lived at the expense of women and children. This representation was used to glorify the new role of men in society and to legitimize the use of arbitrary coercion in the name of good morals, social order, and the elimination of vagrancy. The administrative authorities made it their fundamental mission to 'civilize through work', a crusade that allowed white supervisors to feel like they were making an important contribution . To that end, they had every right to 'make use of all worthy means and methods', which involved brutal physical punishments, fetters, and deportations. The creation of new activities for those men and their families became part of the universal fight against idleness (Portugal, 1953).

The intensification of compulsory work and the legitimation of the use of disciplinary physical violence was sanctioned as early as 1928 with the establishment of the Political, Civil and Criminal Statute of the Indigenous of Mozambique and Angola. This statute was accompanied by the imposition of the odious Indigenous Work Permit (caderneta de trabalho indigena) and the first systematic regulations on forced labour (Martinez 2008, Portugal 1928). Still, under the ministry of João Belo, the 'Belgian model' was adopted for the cotton problem, which was based on forced indigenous labour. As a result, the extension of administrative coercion was accompanied by an increase in internal migrations motivated by compulsory work (recruitment for agricultural work or mines), escape, or the search for better opportunities. Despite the violence of the legal framework established in 1926 and 1928, the authoritarian racist ideology broke with humanitarian principles in order to intensity the mobilization of the African workforce that would continue until the end of the regime. For example, in 1940 the Government Council of the Colony of Mozambique required each man to work at least six months a year in a company, and he was free to choose his boss. However, men could be released from this obligation as long as they worked at least one hectare of land, either in isolation or in the community, 'with crops indicated or recommended by the competent authorities'. Nevertheless, indigenous people would be subject to being recruited by the administrative authority to provide private services for up to nine months each year, whenever there was a lack of 'voluntary labour' in agricultural, commercial, and industrial companies and/or a delay in payment of taxes and fees due to the colonial State (Fernandes 1941).

The formation of the peasant class subordinate to 'traditional authorities' and independent farmers was a relatively slow process. In 1957, for example, the district governor of Mozambique was pleased to refer 'the progressive abandonment of the old [indigenous] notions that prevented men from participating in agricultural work. (...) The hoe, an exclusively female attribute, passed into the hands of men'. Until then he 'only carried out the clearing and helped prepare the crop fields, [now] he starts to collaborate with women in all agricultural operations' (Portugal 1957, I, p.77). Anne Pitcher has shown how women suffered even more than men through the cotton regime, as women were often subject to rape and torture; this included the torture of their children in order to force them to work harder in the cotton fields (Picther 1996).

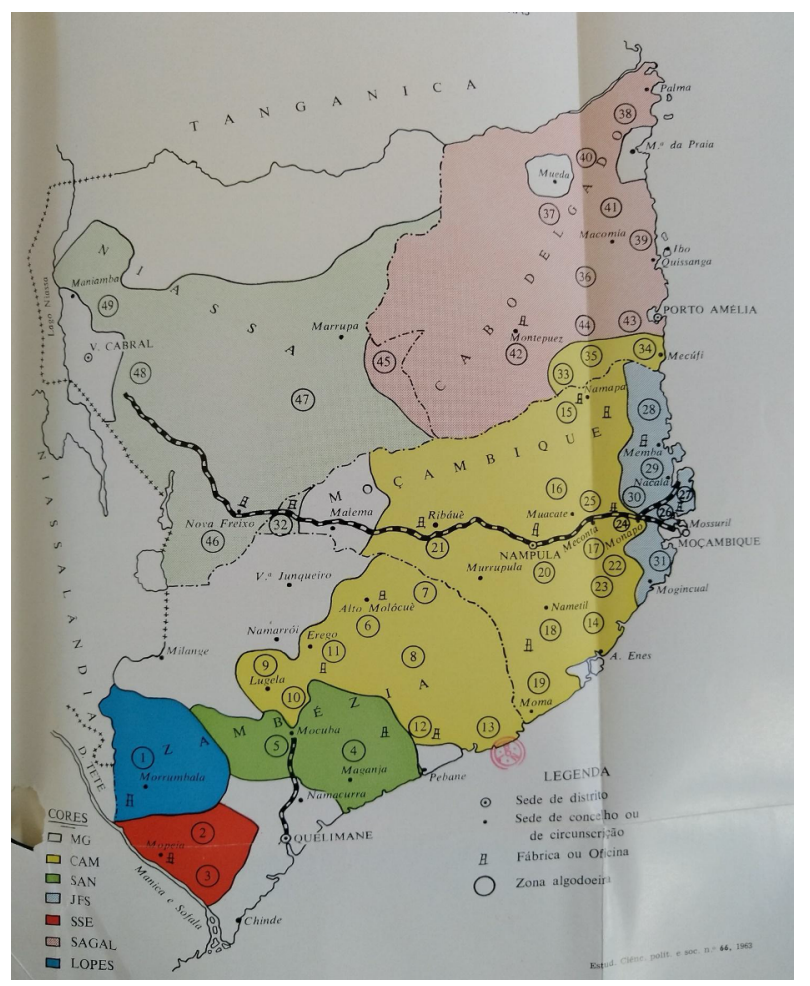

Figure 2: Map of the cotton areas under concession by major exporter firms, and the locations of processing plants in the former districts of Mozambique, Cabo Delgado, and Niassa (Bravo 1963). 
The mobilization of labour required by the cotton industry competed with the needs of European-led commercial agriculture, mining, and other economic sectors. Portugal also contracted the export of black labour in the region south of the Save river with neighbouring countries (South Africa and Rhodesia), which constituted an important source of gold for the colony. The geographical zoning of mandatory crops throughout the territory was administratively managed, and eventually expanded to include the central and northern regions of the territory (former districts of Cabo Delgado, Niassa, and Mozambique).These areas were not subject to intense mobilization until the $1930 \mathrm{~s}$, due to low population density and widespread presence of the tsetse fly. Here, large companies accumulated concessions such as Sociedade Agrícola Algodoeira (SAGAL), Companhia dos Algodões de Moçambique (CAM), Companhia Agrícola e Comercial João Ferreira dos Santos, Companhia Agrícola e Comercial Lopes \& Irmãos, Sena Sugar States Ltd, and Monteiro \& Giro Lda (Figure 2 ). These companies hired agricultural technicians from metropolitan areas in order to create a public image of modernity. Between 1938 and 1961, in the former districts of Zambézia, Mozambique, Cabo Delgado, and Niassa, more than half a million producers cultivated more than 200 thousand hectares (th) each year (Bravo 1963, 135). The prices established by the colonial administration were lower than those paid in the rest of the colony and were well below the prices paid by the English in Kenya, Rhodesia, Nyasaland, or Uganda (Bravo, 1963, 185). The expansion of cotton cultivation accompanied the growing commercialization of indigenous agriculture. Thus, the supply of rice, manioc, corn, and cashew crops increased, while other food crops such as peanuts, beans, and sorghum decreased.

The mobilization of black labour structured new social relationships involving colonial authorities, gentile authorities, recruiting agents, and employers. The cotton agriculture favoured, in some contexts, the feudal leadership style of 'traditional chiefs' who imposed strict rules on labourers in their fields, and exacerbated income inequality in the village communities (Isaacman 1985; Dinnerman 2006, 93-106). The problem of low agricultural productivity had been tackled through scientific research, technical support, and new social engineering measures. For families, the income from cotton was often insufficient to pay the hut tax or even to buy cotton fabrics. Colonial administrators introduced cassava, which altered both local diets and everyday life for the villagers. Because cassava did not require as much labour as other food crops, men had more time to work in the cotton fields. Despite these changes, malnutrition and migration escapes had become endemic.

As of 1946, the creation of cotton concentrations camps (concentrações algodoeiras) was underway, which involved the displacement of populations to lands considered adequate for farming. Each family would receive two hectares of land, technical assistance, and a reduction in the hated hut tax (decree 35,844 of 31 August 1946). These camps were intended to be social and agricultural projects capable of guaranteeing food security, and as such, each camp had a school, a home for the indigenous teacher, and a nursing post with a nurse, a guard, and a foreman (George 1948). After repressing the 'primitive itinerant agriculture', measures were taken to defend the soil against erosion caused by the monocultures, and efforts were made to maintain its fertility with the inclusion of food crops and land rotation. New agricultural tools of metropolitan origin were introduced slowly, and both animal and mechanical technology could be supplied, at least on paper, for the most difficult operation of deforestation in order to prepare the fields for farming.



Figure 3: New cotton concentration camp aligned along the road showing the recently deforested area, partial view. Sagal, Cabo Delgado (Santos 1968). 


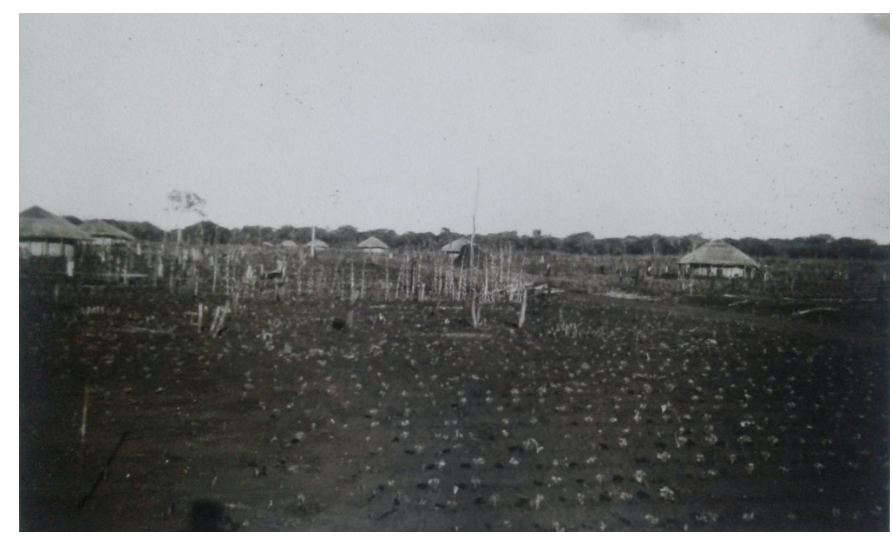

Figure 4: Cotton concentration camp with cotton (first week), Sagal, Cabo Delgado (Santos 1968).

The increase in the number of concentration camps depended to a large extent on the interest and commitment of the concessionary companies and local administrators to mobilize peasants who had been harassed by years of droughts, floods, and plagues, as well as physical punishment and rape by the foremen, agents, and sepoys. The concessionaires had no interest in this scheme because they realized that crop rotation would diminish cotton production, and that indigenous people were not willing to leave their homeland. The burden of environmental risks fell entirely on the farmers, who often petitioned for better pay in order to compensate for these risks. However, local traders often underestimated the quality of cotton in order to avoid paying higher prices. In 1951, in the Mogovolas district, for example, between three and four thousand people died of starvation because of plagues that destroyed cotton crops - a phenomenon that was only noticed when victims of starvation started showing up at the hospital in Nampula (Pitcher 1995, 132). For all these reasons, the percentage of people in cotton concentration camps in Mozambique remained below initial expectations.

The growing efficacy and intensification of the mobilization of black labour by the colonial administration in Cabo Delgado provoked a mass migration to Tanganyika after the 1940s. In 1955, the large Niassa district was divided into three districts, each with their own government (Mozambique, Niassa and Cabo Delgado). Therefore, the administrative network evolved and expanded to control the Northern territory and its peoples. The white sisal producers were then allowed to persecute all indigenous people who did not cultivate cotton extensively. During this time, it was estimated that nearly one hundred thousand men from the Makonde plateau crossed the Rovuma river to work in sisal plantations where the Englishmen offered much better pay. There were also 126 thousand from the Lago (ajauas) and another 100 thousand Makuas from Cabo Delgado that had escaped (Adam 1983,59). New legislation appeared to promote cotton indigenous agriculture, creating the Fundo do Algodão for their "material assistance" and allowing for the creation of 'indigenous cooperatives' under the supervision of the concessionary companies (Decree-Law 40405, November 24th, 1955), thus enabling indigenous farmers to better fulfil their obligations. The Sociedade Algodoeira Africana Voluntária de Moçambique, known as Liguilanilu (meaning 'mutual aid' in the Makonde language) was formed in 1957 in the Mueda plateau. This program became part of a social movement to improve the living standards of black farmers during the time that the 'traditional' lineage structures of society were collapsing. Each family had now four hectares (double than before) and was required to participate in major collective works such as periodic deforestation. In addition, they received seeds and other support from SAGAL, the concessionary company. In practice, the promotion of the cotton concentration camps by other means delivered the costs of labour control to the cooperative leadership (Isaacman 1982; see also Hedges et al. 1993, 235). However, this kind of arrangement was not the norm, and it ended with the Mueda massacre.

\section{Ecological imbalances and the sci- ence of colonial cotton}

Along with the expansion of cotton production came significant advancements in knowledge about cotton monoculture, namely, about plant diseases, fungi, and insect pests. Insects were soon being studied and classified according to their capacity for causing economic damage to commercial agriculture in the colony (Saraiva 1934). The newfound interest in these organisms eventually 
led to the development of agronomic research programs and increased empirical knowledge. This knowledge was the impetus for new agricultural practices that required intensive indigenous labour to support economic growth. Pests and fungi were largely responsible for white farmers' abandonment of monoculture, as these farmers still had to contend with a variety of factors such as price uncertainty in international markets, the fees of exporting intermediaries, access to bank credit, and maintenance of the labour supply. In 1925 and 1926, for example, the circumscriptions of the territory of the majestic Companhia de Moçambique, Neves Ferreira, Manica, Chimoio and Govuro had been severely affected by 'red rust'. Excessive rainfall in April and the lack of nutrients in the soil were considered responsible for the spread of this disease, which affected the production of white farmers.

Red rust, a cotton disease endemic to America, had been discovered in 1904 in German East Africa and in Angola in 1915 by the agronomist Luís Sá Pereira. It reached its peak during 19201924 as a result of various conjunctures that had been favourable to its expansion. The disease caused the leaves to shrink and slowly become covered in red spots; eventually, the foliage would fall and the plant would weaken and die. This could result in crop losses of up to $80 \%$, and could even wipe out the entire production. Fertilization was then considered essential on land that, in many cases, suffered from consecutive years of monoculture. Cotton was more demanding on the soil than corn, and the chartered company was now fighting to convince farmers to persevere, providing them detailed technical instructions for protecting their crops (Companhia de Moçambique 1926).

The storage of large quantities of seed led to the appearance of several types of bedbugs that infested indigenous farms (machambas) throughout the territory (the most frequent species being oxycarenus hyalianipennis). This infestation caused severe damage, because the bedbugs also attacked the capsules after opening them. Bedbugs were also prevalent in Egypt, Sudan, Nyasaland, Madagascar, Somalia and other African cotton regions, as well as in some regions of Mediterranean Europe. Researchers studied them as late as 1950, without ever finding a way to control or eradicate them. Once the oxycarenes had infested a field, they were impossible to eradicate. Therefore, the only solution was to abandon the land and start making successive harvests to reduce the exposure time of the open capsules (Barbosa 1951, 129).

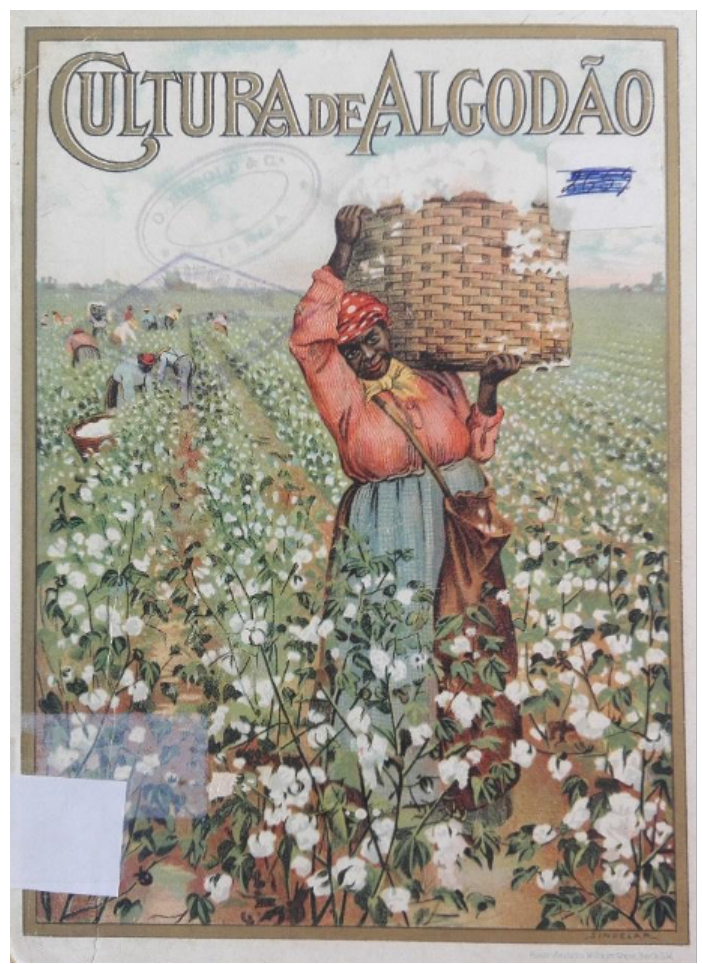

Figure 5: Cover page of the brochure Cotton Culture (in Portuguese) published by the Potassium Salt Mines of Stassfurt (Germany), 1906.

The difficulties and uncertainties regarding the viability of cotton cultivation were great. The need for intensive use of chemicals during various stages of cultivation led German chemical companies to publish brochures in Portuguese at the beginning of the century, detailing how chemicals made cotton more profitable (Figure 5). However, the problems resulting from pests and fungi would have to be solved another way. The colony resorted to the intensification of agricultural work, along with increased mobilization of African villages and constant vigilance in the execution of farming operations. In the late 1940s, an agricultural researcher evaluated the results of the forced indigenous cotton culture: thousands of hectares of forest were cut down annually for land preparation - a task left to the men who hated to do it - and tens of thousands more hectares 
of fertile soil were washed away by the erosive action of rainwater. The practice of incentivizing agricultural labour through physical punishment had resulted in low productivity. The indigenous people were victims of an 'unfortunate policy' that led them 'to hate cotton culture, as it is so often the direct cause of punitive intervention by the authorities'. The apparent success of cotton cultivation had been achieved 'by forcing an excess of indigenous farmers to cultivate extensively on any type of soil without considering the cost of production' (Baptista [1949], 3). The use of chemical fertilizers was limited by the abundance of land and the null cost to the concessionaires of the widespread deforestation.

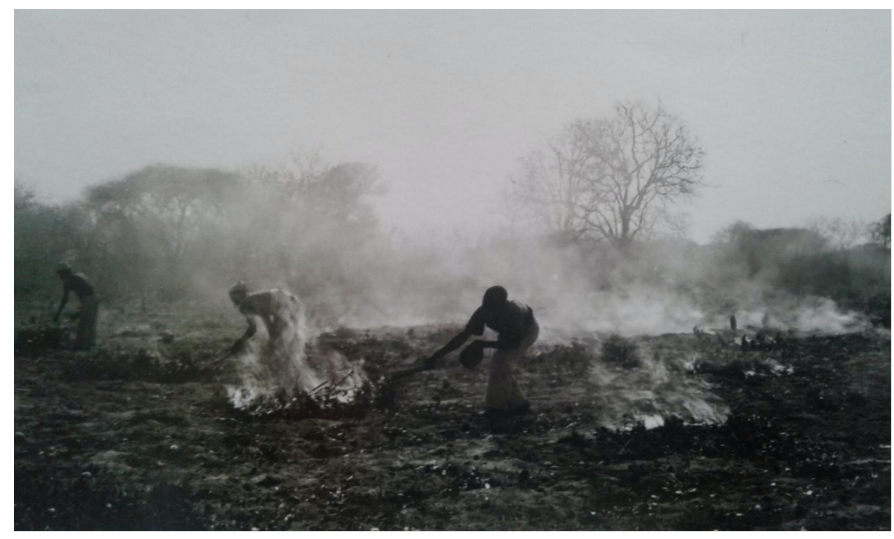

Figure 6: Burning healthy cotton plants at the end of the agricultural cycle to avoid pests - a much-hated compulsory task. Agronomic station of Cotton Institute of Mozambique, Maniquenique, Xai-Xai 1967 (South Mozambique), (Matos 1967-1969).

Of the 465 known insect species that fed on the plant, about one hundred had been identified in Mozambique at the time, of which a dozen affected production, and were responsible for the destruction of about half of annual production (Baptista [1949], 4). Among these were the Red Caterpillar (disparopsis castanea), the Pink Caterpillar (pectinophora gossypiella), the Spiny Caterpillar (earias biplaga and earias insulana) and the Winding Caterpillar (eulia salubricola). There was no way to protect crops against these pests except indirect and prophylactic means, that is, without the use of chemical spraying. These means required 'cotton cultivation right after the first rains and in the least amount of time', and that cotton trees should be uprooted and burned as soon as possible after harvest (Figure 2). Only early varieties of the plant should be sown. Insects of the genus Dysdercus (of the Phyrrhocoridae family), known as Fiber Spots, were the second most important pest and had to be combated by manually collecting them from the plants. It was recommended that nearby trees such as the baobab (adansonia digitata) and kapok (ceiba pentandra) be eliminated in cotton regions, as these trees were a source of food for the insects.

Another way to combat pests was by creating or introducing new varieties of seeds. Jasside, a small Hemiptera, favoured the adoption of the U4 seed and its varieties O52 and 5143, plants that originated in Uganda and were improved in South Africa. The 'cotton improvement' program adapted to different regions was then developed. The Elegant Grasshopper (zonocerus elegans) was also an important pest, especially in the district of Beira and south of river Save, where it was able to destroy the new cotton fields. Children's ranches were used to collect grasshoppers that were bought by the state as a form of encouragement (Baptista [1949], 20).

During the 1930s, the expansion in cotton production had been irregular in the territories of Manica and Sofala under the administration of the chartered company. In 1933, production topped out at 714 tonnes (t), then fell in the following two years, then slowly recovered until 1937, when it peaked at more than 1000 tonnes before falling by half again. In the rest of the territory, however, production had increased successively to 8.2 thousand t., largely thanks to the expansion of farming in the northern districts. The director of agricultural services attributed this success to the increase in production among the indigenous people. The failure in commercial white agriculture was attributed to the fact that seed with good production per hectare and good quality of fibre had not yet been found, due to the region's climate 'and to some imperfections and deficiencies with which the culture is made' (Queiroz 1939, 7).

The practice of 'rational agriculture' was imperative for success. This method involved choosing appropriate land and rotating crops to prevent insect infestations and the rapid depletion of the 
soil (Queiroz 1939, 8-10). These core practices were then augmented by following precise instructions for the preparation of the field, for sowing (leaving adequate space and depth between rows was vital for a good harvest), for the timing of sowing (this varied throughout the regions according to local rainfall patterns), for weeding, for the harvest (the operation that consumed the most time and human energy), and for packaging operations and transportation of the harvest. It was up to the agents of the concessionaire companies to monitor the indigenous farmers and ensure the fulfilment of all these operations. 'After the agents transmit these norms, through the sepoys (...), if any of the indigenous growers do not comply with them, they must report to the respective administrative authority to be punished' (Queiroz 1939, 20). Maintaining cotton production required disciplining the colonized.

Major scientific progress in the research on cotton resulted from the direct influence of the colonial-fascist State. The institutionalization of the research happened relatively late compared with the results already achieved in the English colonies and South Africa. It came after the critical results of nationalist policies designed to control and mobilize the indigenous workforce, and was due, in part, to the corporatism framework. It was only in 1938 that the Junta de Exportação do Colonial (JEA) was created. The JEA was an economic coordination body based in Lisbon, with agencies in Angola and Mozambique, whose mission was 'to promote the improvement of colonial cotton and to increase its production'. The Board of Directors was to include national or foreign technical personnel, thus recognizing that 'the problems of cotton production [should] be studied by competent and specialized technicians', as recommended in 1926 by the American agronomist hired by the government to assess the possibilities of cotton production in Mozambique (Quintanilha 1954). The work of the Cotton Scientific Research Centre (CICA, which included a head office in Mozambique and an agency in Angola) begun as late as 1944 amid 'tremendous difficulties in installation, recruitment of specialized personnel, acquisition and transport of material' due to the war. Its immediate objectives were 'to create varieties that give the highest yields per hectare, the highest percentages of fibre and the best branches for the needs of our textile industry' (Quintanilha 1954).

The training of a group of technicians specialized in different areas of expertise was necessary to deal with the 'cotton problem'. This group was accompanied by the installation of a network of stations and experimental fields in Angola and Mozambique, and by collaboration with foreign research institutes. Its vast agricultural experimentation program involved identifying the most suitable regions and lands for cultivation, choosing the hardiest species and varieties of seeds, and establishing the best agricultural practices. CICA decisively contributed to the improvement of the quality of cotton and to the increase in the productivity of the land and workforce. Between 1943 and 1953, the area being cultivated in the two colonies fell from 360 th to 270 th, while production more than doubled to 130 tt. In Mozambique, the area was reduced by $20 \%$, and demanded the labour of 270,500 indigenous people - $35 \%$ less than before - while production more than doubled. By the 1950s, colonial production had already exceeded the immediate needs of the Portuguese industry. $80 \%$ of cotton was classified as high quality (the cotton varieties Good Middling and Strict Good Middling, 'which practically do not exist in other cotton-producing countries') (Quintanilha 1954). In 1948, the cottonseed (until then without market value) had begun to be used industrially. The industrialization of fibre in the colony for internal consumption was overseen by the elites. The culture of cotton now occupied a high position in the contribution to the 'economic development of Mozambique' (Quintanilha 1966).

CICA disseminated the results of its agronomic research in specialized national and international journals. This research included information on a variety of different categories, including soil erosion, cotton seeds, phyto-economics, agronomic statistics, fungi and pests, agricultural industrialization, and more (Portugal 1948). In 1949, Mário de Carvalho presented the first systematic study of agronomic statistics based on data collected in the cotton experimentation stations of Mozambique between 1942 and 1946 to ascertain the natural factors and cultural practices that determined cotton productivity (Carvalho 
1949). In 1955, the first Ecological-Agricultural Survey of Mozambique was published, which presented systematic rainfall data for the colony. This document was considered fundamental for the success of cotton plantations. This climate of empirical data and agricultural intensification caused the emergence of a movement to 'defend the Mozambican agricultural heritage, putting an end to the senseless deforestation of areas unsuitable for the agricultural exploitation of cotton' (Baptista [1949]).

\section{Economic nationalism and state cor- poratism}

Along with the mobilization of work and science, the new regime instituted a set of policies to guarantee the profits of concessionaires in cotton regions, protecting them from the production risks and price volatility of the world market. Inspired by the 'Belgian model', the 1926 legislation established the fundamental framework for cotton production, defining the principle of concession of cotton areas. That is, the companies should make 'indispensable propaganda about methods of cultivation with the collaboration of the Directorate of Agriculture', and then distribute seeds to the indigenous farmers free of charge. The companies should then buy their cotton production in the area of the concession, in order to defibrate, bale and export it (decrees no. 11,994 and 12,050, of July 28 and of August 4). Propaganda campaigns were considered fundamental and often faced competition from missionaries who tried to convince the local chiefs and the population that cotton would improve their standard of living and combat their social norms surrounding nudity (Isaacman 1985, Manghezi 2003). In other cases, local state administrators raised the value of the hut tax in such a way that there was no alternative for the communities but to cultivate cotton. Concessionaires held a monopoly on the market and were therefore able to fix prices and focus on their task of preparing raw fibre in industrial units and exporting it. However, these tactics achieved disappointing results. In the wake of the 1929 crisis, in the pre-corporatism phase, a colonial cotton export premium was created to compensate the concessionaires for falling prices. At that time, the Cotton Development Fund was created to manage the system and was financed with a new additional tax on all cotton fabrics of foreign origin imported into Angola and Mozambique a measure that would have grave consequences on the price of fabrics used by African women (decree 21,226 of 22 April 1932). An administrative prize was also established for production. The authorities had 'the obligation to carry out a persistent propaganda action among the indigenous' and to provide them with 'efficient technical assistance'. In practice, this legitimized all types of punishments against farmers who did not obey the technical and regulatory instructions issued by the agents of the concessionaires during the vegetative cycle of the plants until they were delivered to the market. To guarantee maximum family production capacity, it was prohibited to recruit indigenous men who lived in the areas surrounding the ginning factories. However, emigration agreements and the requirements of large agricultural operations led to the suspension of this prohibition in Mozambique (Ministerial Order of 22 August 1932). Soon, the regulations on cotton cultivation would be imposed in the vast territory of the chartered Companhia de Moçambique (portaria 7,933 of November 20th, 1934).

The regime favoured the extension and accumulation of cotton fields by the concessionaires. Each area of cultivation could now be up to 120 kilometres long (decree 20,881 of 6 February 1932), and each concessionaire often accumulated several areas in the same region. The concessions, initially awarded for 20 years, were extended for another decade in 1946 (decree 35,844, of $31 \mathrm{Au}-$ gust).

Between 1926 and 1937, the production of colonial cotton almost tripled, but did not yet reach $40 \%$ of the industry's needs. Besides, the quality of this cotton was considered poor. In that year, the Cotton Trade Regulatory Commission was created, and the following year saw the formation of the Colonial Cotton Export Board (JEAC), a coordinating body whose mission was 'to promote the improvement of the quality of colonial cotton and encourage the increase of its production'. In addition, its goals were to 'supervise cotton production and trade in the colonies, especially if the purchase of cotton from the in- 
digenous people is made under the legal conditions and at the established price', and to classify the cotton and propose 'a purchase price of cotton to the indigenous peoples' (decree 28.697 of 25 May 1938). Exporters and commercial producers were obliged to register, with minimum purchase prices attributed to them on an annual basis, which were conditional on the importation of foreign cotton. The imposition of consumption of colonial cotton would lead to the creation of a Regulatory Commission and the National Guild of Raw Cotton Importers.

The 'economic dirigisme' of the colonial-fascist administration led, in the first phase, to the imposition of common procedures for cotton cultivation, such as the definition of acceptable sowing periods. These measures proved to be inadequate and inaccurate over such a vast and diverse geographic territory, and had dramatic consequences on the general population. At the end of World War II, the regime would respond with a legal text addressing the most frequent and most important criticisms made of the 'concession zone regime', namely the fact that the costs resulting from the risks of cotton production fell 'exclusively with the indigenous grower', which often caused them to initiate 'cotton cultivation in less advisable regions' and forced them to abandon food crops. It was recognized that 'the cotton culture, under the regime of zone's concessions, causes distress in the hearts of indigenous societies, causing escapes to neighbouring regions or colonies and creating labour shortages (...) The experience of the Colonial Cotton Export Board reveals, in the many cases that have been observed, the normal independence of cotton culture and the scarcity of food products' (decree 35.844, of 31 August 1946). However, for Salazar's government, the problem of hunger associated with mandatory cotton production was naturalized and relativized based on racist assumptions:

"Endemic famines among some indigenous populations on the black continent are normal and must be affiliated with the naturally indolent and fatalistic psychology of the Bantu peoples. Before Europeans arrived there, the diet of the indigenous people had been as simple as possible, since most of the food products currently used today - corn, manioc, beans, sweet potatoes, peanuts, etc. - were introduced by the white people. With the administrative occupation of African countries, the severity of famines tends to decrease, while its frequency increases. Nevertheless, there is no shortage of people who blame cotton for the famines that are occurring, forgetting that, from one end of the continent to the other, whether or not there is cotton, and without any apparent cause, untimely and endemic famines ravage the region."

The decree of 1946 revoked the previous legislation and reaffirmed the civilizing role of cotton agriculture, binding the 'indigenous to the land' and dictating that each individual should work 'as a self-employed farmer'. Its intention to incorporate the knowledge recently acquired by the CICA, and to rationalize and bureaucratize certain procedures, namely the elimination of areas that were less conducive to cotton production, and the demarcation and promotion of areas considered most favourable. At the same time, a new system was being promoted that would change the rural landscape: the cotton concentration camps (concentrações algodoerias or ruralatos). This new spatial organization of the fields would allow rotations and outcrops, using working cattle and agricultural machinery provided by the concessionaire. The argument for the implementation of the camps had nothing to do with the problem of soil erosion; rather, it focused on the issue of food security, as well as the need to alleviate the problem of chronic labour shortages and to stop migratory escapes. The cotton concentration camps would allow an increase in labour productivity, ensure the 'civilization' of indigenous populations, and free labour for other activities. Thus, concessionaires were compelled 'to watch over the food products of the indigenous people', to promote 'social assistance carried out practically and effectively' and thus, 'to reduce as much as possible the extent of famines within cotton regions' (decree 35.844, of August 31, 1946). However, since the concessionaires did not wish to increase their costs, they resisted promoting cotton concentrations camps, while at the same time, rural populations resisted abandoning their lands, as they preferred to reconcile the demands of cotton production with their existing food 
crops. This required farmers to subject themselves to long hours of intensive work.

Until 1954, colonial production met $90 \%$ of the metropolitan demand. In Mozambique, the mobilization of indigenous farmers decreased after 1945, dropping from 633 to 514 thousand labourers, while production increased from 74 tt to 102 tt. The productivity of the soil increased by $70 \%$ and the productivity of labour by $140 \%$. Despite this success, there were still food supply issues that fell within the jurisdiction of the newly created Cotton Fund (Fundo do Algodão). This organization was permitted to subsidize farmers whose harvests had been harmed by natural causes. In practice, the Fund became a physiocratic organization that aimed to improve the sanitary and economic conditions of indigenous people through environmental, agrarian and social agency. Its contributions included water supply and sanitation improvements for the villages, small agricultural hydraulics for the conservation or drainage of water, as well as technical assistance for farmers who were not aided by concessionaires, agricultural managers or foremen. The Fund provided credit to purchase cattle, simple tools and machinery, as well as to finance construction of silos and housing (of machambeiro type, approved by the governor). Finally, it promoted research on 'cotton readjustment' and provided cinema for 'the education of the indigenous'. Among its staff were agronomists, a forester, a surveyor, a veterinarian, a geophysicist, agricultural technicians and agricultural practitioners, foremen, drillers and their helpers, skilled workers, etc. (Mozambique, 1956).

The 1955 legislation would maintain the fundamentals of economic organization in the following decades (Decree-Law 40405, of 24 November). The authorities were ubiquitous. Cotton culture continued to depend on authorization from the provincial governor, and its trade could only be established in places chosen by the concessionaire, with the approval of the administrative authority. In each zone, cotton could only be grown in the areas demarcated by the Cotton Export Board (JEA). The surface and the limits of each cotton area coincided with the surface and the limits of the municipalities, districts, or administrative posts. The administrative price regime was maintained both for production and sale to the markets. Technical guidance, which was the exclusive responsibility of the Board, would follow the guidelines established by the Nature Protection Council regarding the conservation of soil and flora. The most novel feature of this system was the possibility of creating cooperatives of indigenous people who could directly sell products to concessionaires. Cooperatives came to be seen as 'a vehicle for civilization and a useful method of collaboration'.

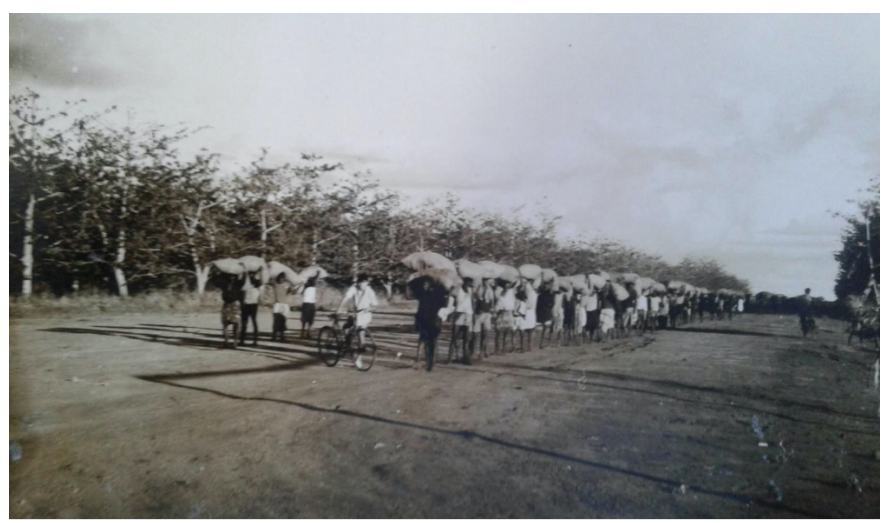

Figure 7: Carrying cotton to sell to the concessionary at the market, Cabo Delgado, 1968. In front, the white man exbibits his bicycle - a highly sought-after item.



Figure 8: One cotton 'market' in Cabo Delgado, 1968.

Cotton cultivation was required to follow the 'plans' for each campaign, which were proposed by the concessionaires and approved by the district governor after hearing the technical body. Mandatory programs were introduced to modify indigenous farming methods and to promote their 
individual and social progress. In 1961, after the Angolan revolt and increasing international criticism, the regime rehearsed one formal 'liberal' opening: cotton concession areas were extinct, and the regime of forced crops and forced work were also both formally abolished (decrees-law 45,179, of August 5, 1963 and 202/71, of May 13).

\section{Cotton killing fields}

The expansion of indigenous cotton fields in Niassa, Cabo Delgado and Mozambique were also dependent on the prevalence of the tsetse fly. From 1921 to 1929, several field expeditions to the territory identified the main areas affected by glossinas. Thus, the process of making land suitable for farming often required building barriers by deforesting large areas, mobilizing large quantities of men, and conducting systematic massive slaughters of wild mammals. Several official hunting campaigns were recorded since 1947 for that purpose, but illegal hunting by white men (including local authorities) was more damaging and became the major concern for conservationists (Gonçalves, 1962, Dias \& Rosinha, 1971a, 1971b). Oxen, cows, and goats occupied some of the new lands, and the human occupation remained at a low density in 1960, -2,3 (Niassa), 6,9 (Cabo Delgado) and 18 (Mozambique district), or 2,2 million people in 278 thousand $\mathrm{km} 2$. The health of the population became a major concern for the governor of this district. He promoted medical inspections of farmers and workers, prevented abuse by local administrators against the indigenous people, and protected cotton farmers' ability to self-produce food crops by not allowing their lands (machambas) to be more than $3 \mathrm{~km}$ away from the cotton fields. He also restricted the practice of forced relocation to cotton concentration camps, and he treated tribal authorities with respect. Indigenous agriculture lacked technical assistance from the companies that did not properly treat the seeds provided to farmers. Cotton was produced with primitive tools, without fertilizers or chemicals, by families that had to support all the major unproductive costs. Meanwhile, the profits of the companies were not re-invested in the colony (AHU/UM/ISAU. 1959, 159). Land ero- sion and exhaustion were now considered major problems.

It was during this time that the Uhuru movement developed in the Makonde plateau, which eventually ended in bloodshed. On June 16, 1960, in the village of Mueda, Faustino Vanomba, Chibilite Vaduvane led thousands of mobilized peasants and proclaimed the return of the Makonde people who had been living and working in Tanganika in the sisal plantations. These migrants had formed the Mozambican African National Union - MANU. Another association for the defence of cotton producers had been formed, the Sociedade Voluntária Algodoeira Africana de Moçambique. This organization was led by Lázaro Nkavandame, another emigrant in Tanganyika, who promised better cotton prices and improved production conditions. Free farms (machambas Liguilanilu) were created in Nacatar, Machomué, Lipelua and Nangade (Adam and Gentili 1983). On June 16, about five thousand people from the Maconde plateau came to the meeting (banja) with the administrator and the governor. After frustrated negotiations, the leaders were arrested. With tensions at a peak, the population, who feared for their lives, advanced in a threatening way on the governor. In the following sequence of events, the sepoys opened fire on the crowd, causing them to flee in disarray. The number of deaths and wounded is uncertain (Cahen 2018; Israel 2017; Schefer 2016, 28).

This conflict, which was rooted in environmental violence, would be mythologized in nationalist narratives. Four years later, on September 25, 1964, an attack on Chai's administrative post (70 kilometres away) signalled the beginning of the armed struggle in Mozambique against Portuguese colonialism. The liberation war had one of its centres in Cabo Delgado, and another in $\mathrm{Ni}$ assa, in northern Mozambique. These became the first 'liberated zones'. Moving in small groups, the guerrillas presented themselves in the villages as liberators. Soon, the main cotton production and trade centres in the North would be transformed into military barracks and war zones. Statistics show that production stagnated in those regions despite the appreciable increase in prices paid to producers since the middle of 1950s.

Since late 1950s, the administrative price of 
cotton paid to producers had begun to increase steadily, thus attracting new white settles. The companies invested in machinery and equipment, and more money began to circulate in rural communities. The share of indigenous cotton started to fall at the time of the attacks against the Portuguese authorities. In 1967, the Cotton Institute promoted new white settlements, each one having one hundred hectares, as well as material and credit support. However, the status of indigenous landowners (now called 'traditional farmers') remained ambiguous under the 'customary law'.

Portuguese newcomers from metropolitan areas arrived to assist in the war efforts, and they soon experienced the harsh climate of the territory, water scarcity, physical and emotional violence, and sometimes death. The war favoured strategies based on the promotion of concentration camps. General Kauza de Arriaga promoted settlements (aldeamentos) and forced mass displacements to separate the populations from FRELIMO's fighters and to 'civilize' them in a hurry. Until this time, even the catholic church had difficulties establishing new missions and rescuing those known as 'indigenas' (now called natives) from their fate. This created a major political conflict. Priests such as Sebastião Soares de Resende (1906-1967), the bishop of Beira, and Manuel Vieira Pinto (1923-2020), who had been in Nampula since 1967 criticized the inhumane treatment of black people. The White Priests missionaries were expelled in 1971, and others were arrested by the political police.

From April 14-18, 1973, the general consuls of the USA, UK, Brazil and Holland visited the aldeamentos in northern Mozambique. The tour included visits to Porto Amelia, Mocimboa da Praia, Mangade, and Montepuez in the Cabo Delgado district; Vila Cabral in Niassa; and Songo and Cabora Bassa in Tete. At the time, there were around 240 aldeamentos with an estimated 300,000 inhabitants in Cabo Delgado and another 120 with approximately 186,450 inhabitants in Niassa. In another war zone, Tete there were 155 aldeamentos with approximately 152,000 inhabitants. Hundreds of new aldeamentos had also recently been built in the Vila Pery, Beira, and Zambesi districts. There were also settlers' plans (colonatos) outside Montepuez and Vila Cabral.
In this period of rapid change, the 'dedication of some of the local Portuguese officials, particularly agricultural engineers, [was] fully comparable to that of British and French district officers in their former African territories during their comparable stage of development prior to independence' (USDF1973). All aldeamentos had water fountains, primary schools and first aid dispensaries, and some 'also included social centre, administrative headquarters and stores'. In the areas they controlled, guerrillas struggled to maintain the support and cooperation of the population Almost 'all aldeamentos were constructed by inhabitants themselves under civil administrative supervision, although military frequently cooperated by providing transport and materials when needed' (Ross 1973). In war zones, aldeamentos were surrounded by barbed wire or 'had other visible defence structures'. In non-war zones, each aldeamento had ten-to-fifteen-armed militia on duty. This led officials to the following conclusion:

"In answer to our query whether inhabitants were happy about being resettled, Portuguese hosts answered, they aren't trying to leave. Consensus seems to be that where resettlement accomplished with adequate advance preparation and not under too much pressure, opposition to moving is minimal" (USDF 1973).

One year later, young Portuguese officers put an end to the authoritarian regime.

\section{Conclusion}

This text focused on the expansion of cotton fields in northern Mozambique during the Estado Novo, to illustrate the processes of major environmental and social change that were integral aspects of the building of the colonial state. The racialized social relationships that marked colonial society developed in symbiosis with the mobilization of scientific research and the new organization of the colonial-fascist state. The State authority was crucial in defining new successful neo-mercantile economic policies by setting favourable cotton prices to exporters and to the Portuguese textile industry, protecting them from the international 
markets. Thus, the regime established compulsory consumption schemes for the metropolitan industry, while promoting coercive indigenous agriculture throughout its vast territory. Efficiency required the creation and mobilization of specialized technical, scientific, and new bureaucratic institutions. Thus, the creation of the new cotton landscapes depended not only on more effective control over the territories and the individuals compelled to work, using disciplinary physical punishment, but also on the investment in science and the creation of anti-liberal organizations.

To Danilo Guimarães, photographer that carried me as a child to Angola and Mozambique in colonial times.

\section{Acknowledgements}

This study was conducted at the Research Center in Political Science (UID/CPO/00758/2020), University of Évora, and was supported by the Portuguese Foundation for Science and Technology and the Portuguese Ministry of Education and Science through national funds.

The author is grateful to Yussuf Adam, Marco Armiero, Roberta Biasillo and to the anonymous reviewers for their comments. He wants to thank Cecília Barata from the Library of Évora (Mitra) for her support and help in the access to documents during research, and Carla Vieira for her help in the reproduction of documents. The author is also grateful to Luís Filipe Ramos, Paolo Israel, Júlio Machele, and Hermenegildo Lange for sharing with him old documents that are not available in Portugal. Finally, he wants to thank Mónica Claesson for revising the text.

\section{References}

[1] Bade, Klaus J. 2002. "Trick or Treat: The Relationship between Destabilization, Aid and Government Devolpment Policies in Mozambique, 1975-1990". PhD thesis Roskild University.

[2] Adam, Yussuf, and Anna Maria Gentili. 1983. "O movimento dos Liguilanilu no planalto de Mueda 1957-1962". In Estudos Moçambicanos, 41-75.

[3] AHU/UM/ISAU. 1959. Arquivo Histórico Ultramarino. Relatório do Governador do Distrito de Moçambique. Typewritten.

[4] Baptista, J. E. 1949. Pragas do algodoeiro em Moçambique. Lourenço Marques: Sociedade de Estudos da Colónia de Moçambique.

[5] Barbosa, A. J. S. 1951. "Estudo da Biologia dos percevejos da semente, do algodão e dos prejuizos causados pelos mesmos". Revista da Faculdade de Ciências, Lisboa, July 28th, 1966. $2^{a}$, I, n. fasc. $1^{o}: 117-132$.

[6] Bravo, Nelson Saraiva. 1963. A cultura algodoeira na economia do norte de Moçambique. Lisboa: Junta de Investigações do Ultramar.

[7] Cahen, Michel. 1983. "Corporatisme et colonialisme. Approche du cas mozambicain, 1933-1979: I. Une genèse difficile, un mouvement squelettique". Cahiers d'études africaines, 23(92): 383-417.

[8] Cahen, Michel. 1984. "Corporatisme et colonialisme. Approche du cas mozambicain, 1933-1979: II. Crise et survivance du corporatisme colonial, 1960-1979". Cahiers d'Études Africaines, 24(93): 5-24.

[9] Cahen, Michel. 2018. "Massacre de Mueda, Moçambique (1960)". In As voltas do passado, 40-47. Lisboa: Tinta da China.

[10] Carvalho, Mário. 1949. "Resultados da experimentação algodoeira em Moçambique". In Agronomia Lusitana. Oeiras: Estação Agronómica Nacional.

[11] Clarence-Smith, W. G. 1985. The third Portuguese empire, 1825-1975: a study in economic imperialism. Manchester University Press.

[12] Correia, Milton M. 2019. "História e textualização: a historiografia da frente do Niassa (Moçambique) 1964-1974. Revista de História, 178: 1-33. São Paulo.

[13] Dias, J. A. Travassos, and Armando J. Rosinha. 1971a. "Terão justificação os abates indiscriminados da caça como medida de luta contra a mosca Tsé-Tsé?: análise do caso de Moçambique". VII Jornadas Médico-Veterinárias. Lourenço Marques.

[14] Dias, J. A. Travassos, and Armando J. Rosinha. 1971b. "Alguns aspectos da caça clandestina em Moçambique...". VII Jornadas Médico-Veterinárias. Lourenço Marques.

[15] Dinerman, Alice. 2006. Revolution, Counter-Revolution and Revisionism in Postcolonial Africa. New York: Routledge.

[16] Fernandes, Vieira. 1941. "Relatório de uma inspecção aos serviços centrais e provinciais. Colónia de Moçambique, 1940-1941". In Arquivo Histórico Ultramarino (Lisboa). ISAC Inspecção Superior de Administração Colonial.

[17] Fortuna, Carlos. 1993. O Fio da Meada: o Algodão de Moçambique, Portugal e a Economia-mundo (1860-1960). Porto: Afrontamento.

[18] George, J. da Fonseca. 1948. Concentrações algodoeiras. In Trabalhos do Centro de Investigação Cientídica Algodoeira: 3-10.

[19] Gonçalves, Celestino. 1962. A Caça em Moçambique. II. Os grandes criminosos da caça. Lourenço Marques. 
[20] Governo do Território da Companhia de Moçambique, Direcção de Agricultura (Secção do Algodão). 1926. Circular sobre a ferrugem vermelha do algodão. Beira.

[21] Hedges, David. 1993. História de Moçambique, Vol. 3, Moçambique no auge do colonialismo, 1930-1961. Maputo: Universidade Eduardo Mondlane.

[22] Isaacman, Allen F. 1982. "The Mozambique Cotton Cooperative: The Creation of a Grassroots Alternative to Forced Commodity Production". In African Studies Review, $25(2 / 3): 5-25$.

[23] Isaacman, Allen F. 1985. "Chiefs, Rural Differentiation and Peasant Protest: The Mozambican Forced Cotton Regime 1938-1961". In African Economic History, University of Wisconsin Press, 14: 15-56.

[24] Isaacman, Allen F. 1990. "Peasants and Rural Social Protest in Africa". African Studies Review, 33(2): 1-120.

[25] Isaacman, Allen F. 1992a. "Coercion, Paternalism and the Labour Process: The Mozambican Cotton Regime 19381961". Journal of Southern African Studies , 18(3): 487-526.

[26] Isaacman, Allen F. 1992b. "Peasants, Work and the Labor Process: Forced Cotton Cultivation in Colonial Mozambique 1938-1961". Journal of Social History, 25(4): 815-855.

[27] Isaacman, Allen F. 1996. Cotton is the mother of poverty: peasants, work, and rural struggle in colonial Mozambique, 1938-1961. Cape Town: Heinemann.

[28] Isaacman, Allen F., and Richard L. Roberts, eds. 1995. Cotton, colonialism, and social history in sub-Saharan Africa. Social history of Africa. Portsmouth, NH: Heinemann.

[29] Israel, Paolo. 2014. In Step with the Times: Mapiko Masquerades of Mozambique. New African Histories. Athens, Ohio: Ohio University Press.

[30] Leite, Joana P. 1989. La Formation de la Economie Coloniale au Mozambique. Pacte Colonial et industrialisation: du colonialisme portugais au réseaux informels de sujeition marchandise, 1930/1974. Paris: EHESS. 2 vols. + anexos

[31] Manghezi, Alpheus. 2003. Trabalho forçado e cultura obrigatória do algodão: o colonato do Limpopo e reassentamento pós-independência c. 1895-1981. Maputo: Arquivo Histórico de Moçambique.

[32] Martinez, Esmeralda Simões. 2008. "O trabalho forçado na legislação colonial portuguesa: o caso de Moçambique: 18991926". Master thesis Faculdade de Letras, Universidade de Lisboa.

[33] Martinho, Jacinto Pereira. 1934. Primeira Exposição Colonial Portuguesa. Porto. Moçambique. A Caça. Lourenço Marques: Imprensa Nacional de Moçambique.

[34] Matos, Emanuel M. 1968. Agronomic Report. Lourenço Marques: Instituto do Algodão de Moçambique.

[35] Moçambique. Fundo do Algodão. 1956. Fundo do Algodão: monografia. Lourenço Marques.

[36] Moçambique. Serviços de Veterinária. 1930. Distribution Géographique des Glossines en Mozambique. Recuil des travaux de reconnaissance... 1921 a 1929. Lourenço Marques.

[37] Moçambique. Serviços de Veterinária. Direcção Geral dos Serviços de Agricultura. 1934a. Algodão. Lourenço Marques.

[38] Moçambique. Serviços de Veterinária. 1934b. A Caça. Lourenço Marques.

[39] Mondlane, Eduardo. 1969. The struggle for Mozambique. Harmondsworth.

[40] Neves, Joel Mauricio das. 1998. "Economy, Society and Labour Migration in Central Mozambique, 1930-1965: A case study of Manica province. University of London. SOAS. School of Oriental and African Studies.
[41] Newitt, Malyn, e Corrado Tornimbeni. 2008. «Transnational Networks and Internal Divisions in Central Mozambique: An Historical Perspective from the Colonial Period». Cahiers d'études Africaines, 48(192): 707-740.

[42] OLaughlin, Bridget. 2002. "Proletarianisation, Agency and Changing Rural Livelihoods: Forced Labour and Resistance in Colonial Mozambique". Journal of Southern African Studies, 28(3): 511-530.

[43] Oliveira, Cintia M. 2019. "O Massacre de Mueda (1960) e a Constituição das Narrativas Nacionais em Moçambique (1962-1986)". PhD thesis Belo Horizonte: UFMG.

[44] Pitcher, M. Anne. 1996. "Conflict and Cooperation: Gendered Roles and Responsibilities within Cotton Households in Northern Mozambique". African Studies Review, 39(3): 81.

[45] Pitcher, M. Anne. 1995. "From coercion to incentives: the Portuguese colonial cotton regime in Angola and Mozambique, 1946-1974". In Cotton, colonialism, and social history in sub-Saharan Africa, 119-145. Portsmouth, NH: Heinemann.

[46] Pitcher, M. Anne. 1991. "Sowing the Seeds of Failure: Early Portuguese Cotton Cultivation in Angola and Mozambique, 1820-1926". Journal of Southern African Studies, 17(1): 43-70.

[47] Portugal, Junta de Exportação do Algodão Colonial. 1948. Trabalhos do Centro de Investigação Científica Algodoeira. Vol. $1^{\circ}$. Lourenço Marques: Tip. Minerva Central.

[48] Portugal, Junta de Exportação do Algodão. 1955. Esboço do Reconhecimento Ecológico-Agrícola de Moçambique. $1^{a}$ ed. 2 vols. Lourenço Marques: Imprensa Nacional de Moçambique.

[49] Portugal, Ministério das Colónias. 1928. Decreto 16199, de 6 de Dezembro. Aprova o Código do trabalho dos indígenas nas colónias portuguesas de África. Diário do Governo, Série I, 281/1928.

[50] Portugal. Ministério das Colónias. 1938. Decreto 45179, de 5 de Agosto. Cria a Junta de Exportação do Algodão Colonial. Diário do Governo, Série I, 119/1938.

[51] Portugal. Ministério do Ultramar, Governo do Distrito de Moçambique. 1942. Relatório do Comandante Eugénio Ferreira de Almeida. 2 vols. Lisboa: Agência Geral das Colónias.

[52] Portugal. Ministério do Ultramar, Governo do Distrito de Moçambique, Governo do Niassa. 1953. "Ordem de serviço 2/52. Política indígena. Normas a seguir." In Portugal, Governo de Distrito de Moçambique. Relatório. 1956, $2^{\circ}$ vol. anexo 1.

[53] Quintanilha, Alexandre. 1948. "Introdução". In Trabalhos do Centro de Investigação Científica Algodoeira, 1(1): 310. Lourenço Marques: Junta de Exportação do Algodão Colonial.

[54] Quintanilha, Alexandre. 1954. O problema algodoeiro português. Lourenço Marques: Imprensa Nacional de Moçambique.

[55] Quintanilha, Alexandre. 1955. "Introdução". In Esboço do Reconhecimento Ecológico-Agrícola de Moçambique, 1: 3-29. Lourenço Marques: Imprensa Nacional de Moçambique.

[56] Quintanilha, Alexandre. 1966. O problema algodoeiro português e a actividade do Centro de Investigação Científica Algodoeira Comunicação apresentada a Classe de Ciências em sessão de 21 de Julho de 1966. Separata. Lisboa: Boletim da Academia das Ciências.

[57] Ribeiro, E. de Queiroz. 1939. O Algodão em Moçambique: instruçôes de cultura para europeus e indígenas (com aplicação especial no Território de Manica e Sofala), 1(3). Beira: Imprensa da Companhia de Moçambique. 
[58] Rufino, José dos Santos. 1929. Álbuns Fotográficos e Descritivos da Colónia de Moçambique, 1(10). Lourenço Marques.

[59] Santos, Censo. 1968. Internship Report. Coimbra: Agronomic School.

[60] Saraiva. 1936. Subsidios para o conhecimento da fauna entomoógico-económica da colónia de Moçambique. Coimbra.

[61] Saraiva, Tiago. 2009. "Laboratories and Landscapes: the Fascist New State and the Colonization of Portugal and Mozambique". Journal of History of Science and Technology, 3: 35-60.

[62] Saraiva, Tiago. 2016. Fascist pigs: technoscientific organisms and the history of fascism. Cambridge, Massachusetts: MIT Press.

[63] Schnurr, Matthew A. 2013. "Cotton as calamitous commodity: the politics of agricultural failure in Natal and Zululand, 1844-1933". Canadian Journal of African Studies, 47(1):115-132.

[64] USDF. US Department of State. Bureau of African Affairs. 1973. Visit to aldeamentos in Northern Mozambique, 25 April (cable).

[65] Vail, Leroy, e Landeg White. 1978. "«Tawani, Machambero!»: Forced Cotton and Rice Growing on the Zambezi". The Journal of African History, 19(2): 239-23.



Paulo Guimarães is an Assistant Professor at the University of Évora and Integrated member of the Research Center in Political Science (CICP). Paulo Guimarães has a $\mathrm{PhD}$ in History from the University of Évora (Portugal), and he is a board member of the Doctoral Programme in Contemporary History at the same university. He is the author of Elites and Industry in Alentejo (1890-1960): a study on economic behaviour of elite groups in regional context (Lisbon, 2005) and of Industry and Conflict in the Rural Milieu: The Miners of Alentejo (1858-1938). 